\title{
Isolation and Identification of Free-Living Amoebae from Tap Water in Sivas, Turkey
}

\author{
Kübra Açıkalın Coşkun, ${ }^{1}$ Semra Özçelik, ${ }^{1}$ Lütfi Tutar, ${ }^{2}$ Nazif Elaldı, ${ }^{3}$ and Yusuf Tutar ${ }^{4,5}$ \\ ${ }^{1}$ Department of Parasitology, Faculty of Medicine, Cumhuriyet University, 58140 Sivas, Turkey \\ ${ }^{2}$ Department of Biology, Faculty of Science and Letters, Kahramanmaraş Sütçü Imam University, \\ 46100 Kahramanmaras, Turkey \\ ${ }^{3}$ Department of Infectious Diseases, Faculty of Medicine, Cumhuriyet University, 58140 Sivas, Turkey \\ ${ }^{4}$ Department of Biochemistry, Faculty of Pharmacology, Cumhuriyet University, 58140 Sivas, Turkey \\ ${ }^{5}$ CUTFAM Research Center, Faculty of Medicine, Cumhuriyet University, 58140 Sivas, Turkey
}

Correspondence should be addressed to Yusuf Tutar; ytutar@cumhuriyet.edu.tr

Received 9 April 2013; Revised 11 June 2013; Accepted 27 June 2013

Academic Editor: Gernot Zissel

Copyright ( 2013 Kübra Açıkalın Coşkun et al. This is an open access article distributed under the Creative Commons Attribution License, which permits unrestricted use, distribution, and reproduction in any medium, provided the original work is properly cited.

The present work focuses on a local survey of free-living amoebae (FLA) that cause opportunistic and nonopportunistic infections in humans. Determining the prevalence of FLA in water sources can shine a light on the need to prevent FLA related illnesses. A total of 150 samples of tap water were collected from six districts of Sivas province. The samples were filtered and seeded on nonnutrient agar containing Escherichia coli spread. Thirty-three (22\%) out of 150 samples were found to be positive for FLA. The FLA were identified by morphology and by PCR using $18 \mathrm{~S}$ rDNA gene. The morphological analysis and partial sequencing of the $18 \mathrm{~S}$ rDNA gene revealed the presence of three different species, Acanthamoeba castellanii, Acanthamoeba polyphaga, and Hartmannella vermiformis. Naegleria fowleri, Balamuthia mandrillaris, or Sappinia sp. was not isolated during the study. All A. castellanii and A. polyphaga sequence types were found to be genotype T4 that contains most of the pathogenic Acanthamoeba strains. The results indicated the occurrence and distribution of FLA species in tap water in these localities of Sivas, Turkey. Furthermore, the presence of temperature tolerant Acanthamoeba genotype T4 in tap water in the region must be taken into account for health risks.

\section{Introduction}

Free-living amoebae (FLA), ubiquitous and widely distributed protozoa, feed on bacteria, algae, fungi, and small organic particles and are adaptable to their environment [1]. They can be found in dust, air, seawater, dental treatment units, sewage, eyewash solutions, contact lenses, and dialysis units and are particularly abundant in soil and water [2,3]. Among them, only four genera including Acanthamoeba, Naegleria, Balamuthia, and Sappinia cause opportunistic and nonopportunistic infections in humans and in animals, but infections are not commonly reported with the exception of Acanthamoeba keratitis which is reported in over 1 to 2 cases per million contact lens wearers in the USA annually [46]. Acanthamoeba spp. and Balamuthia mandrillaris cause granulomatous amoebic encephalitis (GAE) while Naegleria fowleri causes primary amoebic meningoencephalitis (PAM). Both GAE and PAM are central nervous system infections. Some Acanthamoeba spp., commonly Acanthamoeba castellanii, cause amoebickeratitis (AK), a vision-threatening corneal infection. In humans Acanthamoeba spp. may also affect the skin and lungs [3, 7]. Hartmannella spp. invade animal tissues and have been found in nasal mucosa of humans, the bronchial system of dogs, and the intestines of turkeys [8]. Sappinia diploidea have been reported, only once, from a brain infection in a healthy man [9]. This amoeba was identified later as Sappinia pedata, by using real-time PCR tests based on 18S rRNA gene sequences [10].

The presence of FLA in tap water may represent a health risk to both immunocompromised and immunocompetent individuals [11] and they are resistant to extreme conditions of temperature, $\mathrm{pH}$, and exposure to various 


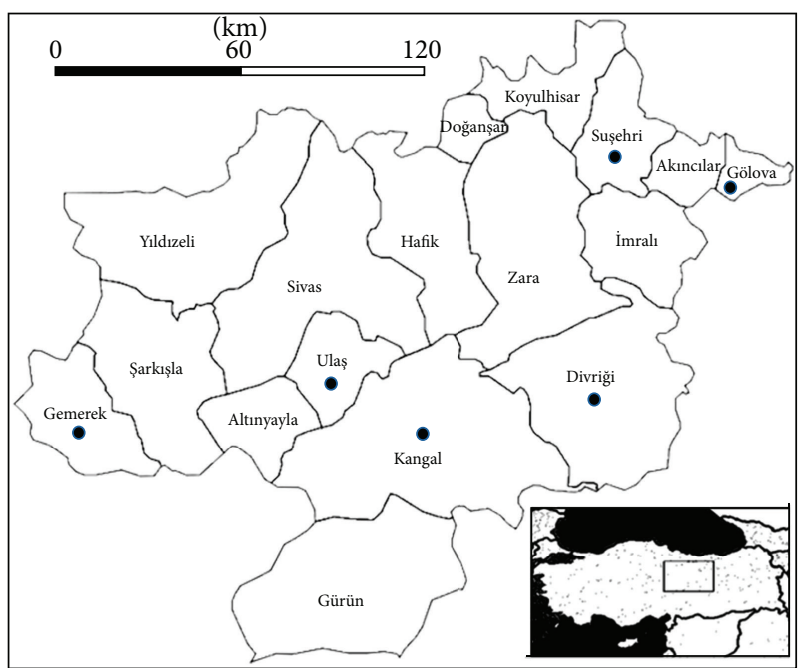

FIGURE 1: Districts of Sivas province and water sample locations (dots), Turkey.

chemicals $[2,5]$. In addition to their pathogenicity, FLA serve as hosts for a large number of pathogenic bacteria and viruses for humans including Legionella spp., Vibrio cholerae, Burkholderia cepacia, Listeria monocytogenes, Escherichia coli O157, Mycobacterium spp., Coxsackievirus, Adenovirus, and Echovirus [2, 5, 11]. Furthermore, FLA can increase virulence of some of the bacteria called amoeba-resisting microorganisms (ARMs) including Mycobacterium spp., Pseudomonas aeruginosa, Legionella spp., Cryptococcus neoformans, and Histoplasma capsulatum [11].

An increase in the number of intracerebral infections caused by FLA in the USA and worldwide has been reported [6].

FLA human infections are documented [12-14], but limited information is available in the literature concerning FLA from the environmental samples in Turkey [15-17]. Therefore, the aim of this study is to isolate FLA from tap water samples collected from various districts in the province of Sivas by employing morphological and molecular methods in order to contribute to the study of understanding their ecology and to identify any potential health risks.

\section{Subjects and Methods}

2.1. Study Location, Sampling, Isolation, and Identification of Amoebae and DNA Extraction. A total of 150 tap water samples were collected between March and August 2011 from the districts of Divriği, Kangal, Suşehri, Ulaş, Gölova, and Gemerek of Sivas province, located in the central Anatolia region of Turkey. The total surface area of Sivas province is $28500 \mathrm{~km}^{2}$ and the study area is about $10000 \mathrm{~km}^{2}$ (Figure 1). Sivas is located at the junction of different regions and reflects typical climates of Turkey's various regions. Therefore, a prevalence study in a transition region like Sivas may reflect overall Turkish FLA distribution.

All samples (except two of them, see Table 2) in this study were chlorinated by the city officials in drinking water plant according to world health organization criteria (0.2$0.7 \mathrm{ppm})$.

A total of $500 \mathrm{~mL}$ of water sample was collected from each tap focus in a sterile plastic container from different villages and districts. They were then immediately transferred to the laboratory. FLA were isolated from the samples as previously described elsewhere $[7,18]$. Briefly, water samples were filtered through $0.45 \mu \mathrm{m}$ pore size cellulose nitrate membrane filter ( $47 \mathrm{~mm}$ in diameter) under a vacuum. The membrane filters for each water sample were scraped and collected materials were placed in $15 \mathrm{~mL}$ of sterile cover tubes containing $10 \mathrm{~mL}$ phosphate buffered saline (PBS). Tubes were incubated at room temperature overnight and then centrifuged for ten minutes at $1500 \mathrm{rpm}$ to collect particles on filters. After centrifugation, the supernatant solution was discarded and the pellet was inoculated onto $1.5 \%$ nonnutrient agar (NNA) plates. A dense suspension of heat inactivated Escherichia coli, prepared in Page Saline, was seeded onto NNA plates to grow FLA. After the inoculation of the samples, all plates were incubated at $30^{\circ} \mathrm{C}$ and examined daily for the presence of FLA for up to 10 days using a light microscope (100x). Once a growth was observed, a piece of NNA containing the amoebae was excised to inoculate a fresh NNA plate to subculture and incubated until trophozoites were grown. Then, the trophozoites were scraped to isolate genomic DNA (QIAmp DNA Mini Kit, QIAGEN).

Amoebae were isolated and identified by morphologic features as well as PCR based sequence analysis. Smirnov and Goodkov's basic morphotyping list was used to identify amoebae [19]. Acanthamoeba was identified both by acanthopodia in the trophozoite form and by double-layered polygonal walls in the cysts form (Figure 2(a)). The Hartmannella was identified by smooth, spherical appearance (Figure 2(b)) $[16,20]$. A temperature tolerance test was also performed for Acanthamoeba: three sets of subculture plates (NNA-E. coli) for each sample were incubated at 37, 42, and $52^{\circ} \mathrm{C}$, respectively. All plates were examined daily for amoebal growth by phase contrast microscopy for seven days [21]. When an FLA strain was isolated, the flagellate transformation test was applied for the identification of $N$. fowleri [20]. All FLA strains were transferred to a fresh NNAE. coli plate every month to check their viability and each of them were used in the experiments.

\subsection{PCR Amplification, Sequencing, Blast Search of Sequenced} Amplicons, and Cluster Analysis of Amoebae. Acanthamoeba, N. fowleri, B. mandrillaris, and Sappinia genus specific primer pairs along with common amoebae specific primers (Table 1) were employed in molecular detection of the amoebae species $[7,10,22-24]$. Fifty $\mu \mathrm{L}$ of PCR mixture contained $1 \mathrm{ng}$ DNA, $5 \mu \mathrm{L} \mathrm{10x}$ Taq buffer, $5 \mu \mathrm{L} 2 \mathrm{mM}$ dNTP, $4 \mu \mathrm{L} 25 \mathrm{mM}$ $\mathrm{MgCl}_{2}, 0.5 \mu \mathrm{L} 100 \mathrm{mM}$ primer, $0.5 \mu \mathrm{L}$ Taq DNA Polymerase. The thermal cycling conditions were an initial incubation of $94^{\circ} \mathrm{C}$ for $7 \mathrm{~min}$ and 45 cycles of $94^{\circ} \mathrm{C}$ for $60 \mathrm{~s}\left(95^{\circ} \mathrm{C}\right.$ for Acanthamoeba), $\mathrm{X}^{\circ} \mathrm{C}$ for $60 \mathrm{~s}$, and $72^{\circ} \mathrm{C}$ for $60 \mathrm{~s}$ with a terminal extension of $72^{\circ} \mathrm{C}$ for $10 \mathrm{~min}\left(\mathrm{X}=55^{\circ} \mathrm{C}\right.$ for Naegleria, Sappina, and Balamuthia; $60^{\circ} \mathrm{C}$ for Acanthamoeba; and $65^{\circ} \mathrm{C}$ for common primers). PCR reactions were performed to amplify $18 \mathrm{~S} \mathrm{rDNA}$ sequences. These primers 


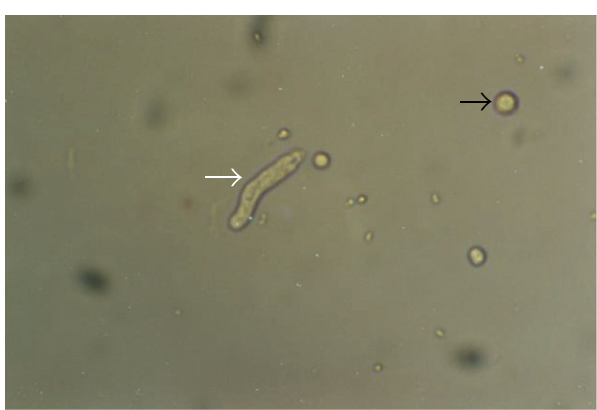

(a)

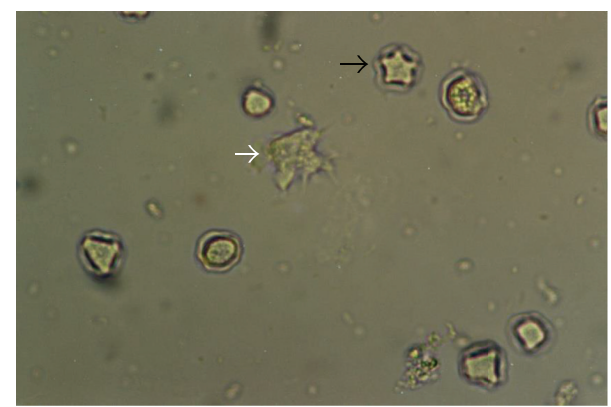

(b)

Figure 2: Hartmannella (a) and Acanthamoeba (b) trophozoites (white arrow), cyst forms (black arrow) (original magnification; 40x).

yielded 750-1000 bp fragments. The PCR amplicons were separated by $1 \%$ agarose gel (data not shown but available on request). Amplicon sizes were estimated using a DNA ladder. Amplicons were gel purified prior to sequencing. Sequencing was unidirectional (5-GTCAGAGGTGAAATTCTTGG$\left.3^{\prime}\right)$. Nucleotide similarity search was performed by blast search (basic local alignment search tool) of sequenced amplicons against amoeba species. Acanthamoeba has been classified into genotypes based on 18S ribosomal RNA nucleotide sequencing recently $[25,26]$. GenBank accession numbers of these species are given in Table 2. Morphological observations and sequencing yielded three different species: A. castellanii, Hartmannella vermiformis, and A. polyphaga.

Cluster analysis was performed for FLA by using the latest version of MEGA 5.05 software [27]. Phylogenetic construct was produced by employing $18 \mathrm{~S}$ rRNA gene sequences and amoebae genus $18 \mathrm{~S}$ rDNA gene sequences accession numbers listed in Table 2. These were aligned with the corresponding sequences from 33 reference Acanthamoeba isolates, and a neighbor-joining tree was obtained using MEGA 5.05 (Figure 3) [27].

\section{Results}

FLA were detected in 33 (22\%) out of 150 water samples in six Sivas districts. All Hartmannella isolates $(n=24)$ were identified as $H$. vermiformis and except one isolate, which was identified as A. polyphaga, all Acanthamoeba isolates $(n=8)$ were identified as A. castellanii. No representative of any of the other three genera of FLA of clinical relevance, Balamuthia, Naegleria, and Sappinia, was present in any of the samples (Table 2). It was observed that all Acanthamoeba isolates were capable of growth at all incubation temperatures and they grew easily and fast at $37^{\circ} \mathrm{C}$ incubation but the amoeba trophozoites grew slower at either $42^{\circ} \mathrm{C}$ or $52^{\circ} \mathrm{C}$ of incubations. After two days of incubation, respective Acanthamoeba isolates stayed alive at $42^{\circ} \mathrm{C}$ (samples numbers, 2 , $13,19,27,30,32$, and 33 ) and at $52^{\circ} \mathrm{C}$ (samples numbers, 2,13 , $27,30,32$, and 33 ). The flagellate transforming test was found to be negative for all the 33 isolates.

Morphological identification of amoebae revealed Acanthamoeba and Hartmannella trophozoites. Acanthamoeba strains belong to the T4 genotype as confirmed by genus specific primer pair (Table 1).

The main target of the current study was to apply and evaluate molecular methods to recognize FLA along with classical microscopic determination method. We used PCR primers to diagnose FLA species by employing a general primer set and four genus specific primer sets (Table 1). In this study FLA isolates were compared to GenBank and the reference strains (Table 2) to determine species. PCR amplicon lengths varied from 500 to 1000 base pairs.

Acanthamoeba isolates were further examined by phylogenetic analyses by comparison of sequenced amplicons to Acanthamoeba strains. This included all representative sequences available from GenBank. All Acanthamoeba isolates were clustered in sequence type group $\mathrm{T} 4$.

A homology search was performed with BLAST from NCBI. The deduced sequences were aligned by ClustalW with FLA sequences and the phylogenetic tree was then displayed by neighbor-joining analysis conducted with MEGA (Figure 3). All sequences gave $100 \%$ similarity except sample number 2 (99\%) with accession numbers being given in Figure 3. In the phylogenetic tree Acanthamoeba and Hartmannella species clustered in different branches but sequences of the same genus clustered together in the same branch. This shows their genetic similarity to a certain degree and consistency with identification of isolated samples.

Neighbor-joining gene tree analysis identifies individual strains of the isolates obtained in this study as revealed by reference numbers given at Table 2 . The phylogenetic analysis illustrated that Acanthamoeba isolates were clustered to pathogenic genotype T4 and closest to U07413 reference number. However, two Acanthamoeba isolates belong to the U7413 and U07407 reference numbers. Similarly, Hartmannella isolates belong to the AF426157 reference number.

The phylogenetic analysis confirms clinically relevant amphizoic amoebae in tap water which may present a risk to people's health.

\section{Discussion}

FLA were distributed worldwide and the composition of these species at certain locations depends on the surroundings. Also, the spreading of FLA species depends on its 
U07401.1 CDC:0184:V014 18S rRNA gene

AF019068.1 BH-2 18S ribosomal RNA gene partial sequence

AF019063.1 2802 18S ribosomal RNA gene partial sequence

AF019058.1 Vazaldua 18S ribosomal RNA gene partial sequence

U07404.1 ATCC 50498 18S ribosomal RNA gene complete sequence

U07406.1 BCM:0685:116 ATCC 50368 18S rRNA gene

AF019056.1 HC-2 18S ribosomal RNA gene partial sequence

U07407.1 BCM:0173:16 ATCC 50371 18S rRNA gene

U07414.1 ATCC 50370 18S rRNA gene

S81337.1 18S rRNA H37 genomic $2781 \mathrm{nt}$

U07400.1 CDC:0981:V006 18S rRNA gene

AF019052.1 Panola Mountain 18S ribosomal RNA gene partial sequence

U07416.1 ATCC 50373 18S rRNA gene

AF019060.1 2AX1 18S ribosomal RNA gene partial sequence

AF019062.1 Nagington 18S ribosomal RNA gene partial sequence

U07408.1 ATCC 50496 18S ribosomal RNA gene complete sequence

AF019055.1 Liu-E1 18S ribosomal RNA gene partial sequence

U07412.1 S-7 ATCC 30731 18S rRNA gene

43 AF019059.1 Rodriguez 18S ribosomal RNA gene partial sequence

AF019050.1 GE3a 18S ribosomal RNA gene partial sequence

U07411.1 ATCC 30870 18S rRNA gene

U07413.1 ATCC 50374 18S rRNA gene

U07405.1 CDC:0180:1 18S rRNA gene

U07402.1 CDC:0884:V029 18S rRNA gene

U07417.1 Oak Ridge ATCC 30884 18S rRNA gene

AF019061.1 18S ribosomal RNA gene partial sequence

U07410.1 ATCC 50497 18S ribosomal RNA gene complete sequence

AF019051.1 OX-1 18S ribosomal RNA gene partial sequence

AF019053.1 18S ribosomal RNA gene partial sequence

U07403.1 CDC:0786:V042 18S rRNA gene

58 U07415.1 JAC/S2 ATCC 5037218 S rRNA gene

AF019057.1 Diamond 18S ribosomal RNA gene partial sequence

U07409.1 ATCC 50369 18S ribosomal RNA gene complete sequence

AF019054.1 Jin-E5 18S ribosomal RNA gene partial sequence

AF019067.1 Lilly A-1 18S ribosomal RNA gene partial sequence

AF019069.1 RB:F:1 18S ribosomal RNA gene partial sequence

AF019070.1 18S ribosomal RNA gene partial sequence

U94741.1 PD2S 18S small subunit ribosomal RNA gene partial sequence

U94738.1 NJSP-3-2 18S small subunit ribosomal RNA gene partial sequence

U94730.1 $4518 \mathrm{~S}$ small subunit ribosomal RNA gene partial sequence

U94732.1 72/2 18S small subunit ribosomal RNA gene partial sequence

U94733.1 68-2 18S small subunit ribosomal RNA gene partial sequence

U94731.1 7327 18S small subunit ribosomal RNA gene partial sequence

75 U94735.1 E18-2 18S small subunit ribosomal RNA gene partial sequence

U94736.1 118 18S small subunit ribosomal RNA gene partial sequence

U94737.1 53-2 18S small subunit ribosomal RNA gene partial sequence

43 U94740.1 25/1 18S small subunit ribosomal RNA gene partial sequence

U94739.1 Jc-1 18S small subunit ribosomal RNA gene partial sequence

U94734.1 407-3a 18S small subunit ribosomal RNA gene partial sequence

HM363627.1 GERF2 small subunit ribosomal RNA gene partial sequence

FR820592.1 MTZ genomic DNA containing 18S rRNA gene

AB425953.1 Mbc 3H gene for 18S ribosomal RNA

EF378675.1 T5-5 18S ribosomal RNA (rrn) gene

EF378674.1 T5-4 18S ribosomal RNA (rrn) gene

EF378671.1 T3-3 18S ribosomal RNA (rrn) gene

EF378670.1 T3-1 18S ribosomal RNA (rrn) gene

AF426157.1 18S ribosomal RNA gene

M95168.1 small subunit ribosomal RNA

AY680840.1 18S ribosomal RNA gene

AY502961.1 isolate KWR-3 18S ribosomal RNA gene

AY502960.1 isolate KWR-2 18S ribosomal RNA gene

AY502959.1 isolate KWR-1 18S ribosomal RNA gene

HM363626.1 GERF1 small subunit ribosomal RNA gene

92 HQ007037.1 strain D113 18S ribosomal RNA gene

FJ940709.1 18S ribosomal RNA gene

GQ996535.1 isolate A3 18S ribosomal RNA gene

FJ940710.1 isolate 12i 18S ribosomal RNA gene

HQ833442.1 isolate LN-HB5 18S ribosomal RNA gene

AB525839.1 18S ribosomal RNA

AB525837.1 18S ribosomal RNA

AB525835.1 18S ribosomal RNA

AB525834.1 18S ribosomal RNA

HQ833443.1 isolate LN-B14 18S ribosomal RNA gene

AB525836.1 18S ribosomal RNA

HQ833444.1 isolate LN-HD12 18S ribosomal RNA gene

FJ940716.1 isolate 2e 18S ribosomal RNA gene

AF019064.1 Ray Hayes 18S ribosomal RNA gene partial sequence

AF019065.1 OC-15C 18S ribosomal RNA gene partial sequence

AF019066.1 Comandon de Fonbrune 18S ribosomal RNA gene partial sequence

AY576365.1 546 18S ribosomal RNA gene

99 AY576364.1545 18S ribosomal RNA gene

FIGURE 3: Phylogenetic analysis of FLA isolates. Neighbor-joining tree based on $18 \mathrm{~S}$ rDNA sequences. The sequences from Sivas isolates were aligned by MEGA software using reference isolates from GenBank. Bar is index of evolutionary distances (0.2) among the different sequences. The numbers on the branch nodes of phylogenetic tree corresponded to bootstrap value. 
TABle 1: Primers used in this study $\left(5^{\prime} \rightarrow 3^{\prime}\right)$.

\begin{tabular}{lccc}
\hline Species & Forward primer & Reverse primer & Reference \\
\hline Common for FLA & CGCGGTAATTCCAGCTCCAATAGC & CAGGTTAAGGTCTCGTTCGTTAAC & Tsvetkova et al., 2004 [7] \\
Acanthamoeba spp. & GGCCCAGATCGTTTACCGTG & TCTCACAAGCTGCTAGGGAGTCA & Schroeder et al., 2001 [22] \\
N. fowleri & CAAACACCGTTATGACAGGG & CTGGTTTCCCTCACCTTACG & Schild et al., 2007 [23] \\
B. mandrillaris & CGCATGTATGAAGAAGACCA & TTACCTATATAATTGTCGATACCA & Booton et al., 2003 [24] \\
Sappinia & TCT GGT CGC AAG GCT GAA AC & GCA CCA CCA CCC TTG AAA TC & Qvarnstrom et al., 2009 [10] \\
\hline
\end{tabular}

FLA: Free-living amoebae.

TABLE 2: Species, genotypes, GenBank accession numbers, and isolation sources of free living amoebae in districts of Sivas, Turkey.

\begin{tabular}{|c|c|c|c|c|}
\hline No. & Species, identified & Genotype & Gene Bank ref. no. & Source of tap water \\
\hline 1 & Acanthamoeba castellanii & $\mathrm{T} 4$ & U07403 & Divriği village \\
\hline 2 & Acanthamoeba castellanii & $\mathrm{T} 4$ & U07413 & Kangal village \\
\hline 3 & Hartmannella vermiformis & & AF426157 & Suşehri village \\
\hline 4 & Hartmannella vermiformis & & AF426157 & Kangal village \\
\hline 5 & Hartmannella vermiformis & & AF426157 & Kangal village \\
\hline 6 & Hartmannella vermiformis & & AF426157 & Kangal village \\
\hline 7 & Hartmannella vermiformis & & AF426157 & Kangal city center* \\
\hline 8 & Hartmannella vermiformis & & AF426157 & Suşehri village \\
\hline 9 & Hartmannella vermiformis & & AF426157 & Suşehri village \\
\hline 10 & Hartmannella vermiformis & & AF426157 & Kangal village \\
\hline 11 & Hartmannella vermiformis & & AF426157 & Suşehri village \\
\hline 12 & Hartmannella vermiformis & & AF426157 & Divriği village \\
\hline 13 & Acanthamoeba castellanii & $\mathrm{T} 4$ & U07413 & Kangal village \\
\hline 14 & Hartmannella vermiformis & & AF426157 & Ulaş village \\
\hline 15 & Hartmannella vermiformis & & AF426157 & Suşehri village \\
\hline 16 & Hartmannella vermiformis & & AF426157 & Divriği village \\
\hline 17 & Hartmannella vermiformis & & AF426157 & Gölova village \\
\hline 18 & Hartmannella vermiformis & & AF426157 & Divriği village \\
\hline 19 & Acanthamoeba castellanii & $\mathrm{T} 4$ & U07413 & Kangal village \\
\hline 20 & Hartmannella vermiformis & & AF426157 & Kangal village** \\
\hline 21 & Acanthamoeba castellanii & $\mathrm{T} 4$ & U07413 & Kangal village \\
\hline 22 & Acanthamoeba castellanii & $\mathrm{T} 4$ & U07413 & Divriği hospital \\
\hline 23 & Hartmannella vermiformis & & AF426157 & Suşehri village \\
\hline 24 & Hartmannella vermiformis & & AF426157 & Ulaş healthcare center \\
\hline 25 & Hartmannella vermiformis & & AF426157 & Gemerek village \\
\hline 26 & Hartmannella vermiformis & & AF426157 & Kangal village \\
\hline 27 & Hartmannella vermiformis & & AF426157 & Kangal village \\
\hline 28 & Hartmannella vermiformis & & AF426157 & Suşehri village \\
\hline 29 & Hartmannella vermiformis & & AF426157 & Ulaş village \\
\hline 30 & Acanthamoeba castellanii & $\mathrm{T} 4$ & U07413 & Kangal village \\
\hline 31 & Hartmannella vermiformis & & AF426157 & Suşehri village \\
\hline 32 & Acanthamoeba polyphaga & $\mathrm{T} 4$ & U07407 & Ulaş village \\
\hline 33 & Acanthamoeba castellanii & $\mathrm{T} 4$ & U07413 & Kangal village \\
\hline
\end{tabular}

${ }^{*}$ Spring water.

${ }^{* *}$ Fountain water.

tolerance to survive under adverse conditions. Therefore, the ecological importance of FLA must be adequately studied to prevent fatal human diseases. In this present comprehensive study, waterborne amoebae were isolated in various districts of Sivas province. We found FLA nearly in one out of five water sources in Sivas districts. Results revealed that
Acanthamoeba and Hartmannella have a high distribution in the samples compared to other FLA. Although specific primers were designed, we did not isolate any of $N$. fowleri, B. mandrillaris, and Sappinia sp. during the study. This could be due to a lower prevalence of such FLA in the environment. Our findings are in agreement with a study from Bulgaria 
[7]. This Bulgarian study group determined Acanthamoeba and Hartmannella abundantly in water and soil samples compared to other species in Bulgaria. The high prevalence of the above FLA in human-related habitats was observed in environmental freshwaters of several countries as reported by the studies [28, 29].

Acanthamoebae have been isolated previously from bottled drinking water, tap water, soil, and dust in Burdur and İstanbul provinces in Turkey [15]. Furthermore both Acanthamoebae and Naegleria have also been isolated from soil and thermal water specimens in our region [16]. However, in that study, the amoebae have not been identified below the genus level. In our study except Naegleria we have also shown the presence of Acanthamoeba in the same region and identified those species. Acanthamoeba isolates belonging to T2, T3, T4, and T7 genotypes from Ankara [17] and T4 and T9 genotypes from Aydin province [13] have been found in environmental samples in Turkey.

To our knowledge the presence of FLA in the environment does not mean a risk factor for illness. However, many species of Acanthamoeba are potentially pathogenic for animals and for humans. A. castellanii, A. polyphaga, and $A$. culbertsoni are the most common species to infect humans [30,31]. Acanthamoeba spp. are the main cause of AK associated with contact lenses [2,3], although cases involving Hartmannella sp. have also been described [32]. H. vermiformis has been suggested as a cause of AK but this is still under debate by other investigators [33]. In a study performed in Aydin province, in the western part of Turkey, a case of AK caused by a genotype T4 Acanthamoeba strain related possibly with source of tap water was reported [13]. Another genotype, T4 Acanthamoeba strain, was also reported in an AK case in İzmir province, a neighbor province of Aydin. Tap water has been assumed to be the most important source of AK caused by genotype T4 Acanthamoeba [7] and worldwide the most important AK-causing strains are associated with genotype T4 [34, 35].

Acanthamoeba can tolerate extreme temperatures and thus become cold resistant, $A$. polyphaga may survive below $4^{\circ} \mathrm{C}$. Some strains of Hartmannella can tolerate up to $48^{\circ} \mathrm{C}$ $[11,36]$. Since Sivas province is a place of extreme hot and cold temperatures during the year, we conclude that determined FLA species are tolerant to ecological conditions. Air temperature ranges between winter and summer have been reported as -34.6 to $40^{\circ} \mathrm{C}$ during the years of 1972 to 2011 in Sivas (Turkish State Meteorological Service at http://www.dmi.gov.tr). In addition to environmental temperature conditions, several other factors such as cyst structure and surface availability of the organism, $\mathrm{pH}$ alterations, and osmolarity changes in water also determine the FLA life [37].

Acanthamoeba spp. and Hartmannella spp. can harbor pathogenic microorganism which indicates the importance of these amoebae to public health. Acanthamoeba T4 genotype and $H$. vermiformis may be infected naturally by pathogenic ARMs. Acanthamoeba T4 genotype may be infected by Legionella sp. and Neochlamydia sp., whereas $H$. vermiformis may be infected by Neochlamydia sp. and Legionella donaldsonii [37]. FLA can facilitate growth and transportation of waterborne pathogens. Therefore, they are used by pathogenic waterborne ARMs to proliferate in drinking water systems. We have limited data about host FLA in drinking water. It was reported previously that the infected FLA rate by ARM in drinking water system was 16\% [5]. It is likely that several other infected FLA by unidentified pathogenic ARMs are yet to be determined.

Interestingly, FLA detection reported the presence of several genera of FLA, namely, Acanthamoeba, Naegleria, and Hartmannella, at different stages of the water treatment in drinking water treatment plants [38, 39]. Furthermore, Hartmannella spp. have been reported to resist disinfection in treatment plants $[38,39]$. Acanthamoeba spp. can resist water treatment for sanitizing drinking water as well [28]. This data is consistent with our findings since 24 out of 33 detected FLA were $H$. vermiformis and 9 out of 33 detected FLA were Acanthamoeba spp. (Table 2). One other reason is that the high $H$. vermiformis prevalence in our region might be due to high levels of active biomass and natural organic matter [40] since agriculture and animal husbandry is common in Sivas province.

\section{Conclusions}

The results indicated the presence of $A$. castellanii, $H$. vermiformis, and $A$. polyphaga in tap water in Sivas localities. Furthermore, presence of temperature tolerant Acanthamoeba $\mathrm{T} 4$ genotypes in the region must be taken into account for AK.

FLA were underestimated by medical community until some species of amebae caused systemic infections in immunocompromised individuals. The amebic diseases are difficult to determine clinically and a patient may suffer from delay in treatment. Further, this delay may lead to deadly infections and cause fatal cases. Therefore, an investigation of the connection between environment and the patient's infections is essential. An individual history including interaction with amebic water and inhalation of cysts during dust storm may help a physician to diagnose the infection. Knowledge of prior prevalence of amebae in the region may help physicians to diagnose and treat either healthy or immunocompromised individuals. Clinicians may benefit from the reported data in the treatment of amebae related infections. Presence of FLA can lead to take precautions and reported FLA distribution can help understand the potential threat to the health of individuals.

The data obtained from the study may be beneficial for the clinicians and the environmental professionals in the region and regions around the world that have similar ecological conditions.

\section{Conflict of Interests}

The authors declare no conflict of interests.

\section{Authors' Contribution}

Y. Tutar was the principal investigator and takes primary responsibility for the paper. K. A. Çoşkun and L. Tutar 
performed the experiments. N. Elaldı and S. Özçelik coordinated the research. Y. Tutar wrote the paper.

\section{Acknowledgment}

This work was funded by a seed grant from the Turkish National Academy of Sciences (TUBA-GEBIP).

\section{References}

[1] L. J. Stockman, C. J. Wright, G. S. Visvesvara, B. S. Fields, and M. J. Beach, "Prevalence of Acanthamoeba spp. and other freeliving amoebae in household water, Ohio, USA-1990-1992," Parasitology Research, vol. 108, no. 3, pp. 621-627, 2011.

[2] H. Trabelsi, F. Dendana, A. Sellami et al., "Pathogenic freeliving amoebae: epidemiology and clinical review," Pathologie Biologie, vol. 60, no. 6, pp. 399-405, 2012.

[3] A. J. Martinez and G. S. Visvesvara, "Free-living, amphizoic and opportunistic amebas," Brain Pathology, vol. 7, no. 1, pp. 583598, 1997.

[4] G. S. Visvesvara, H. Moura, and F. L. Schuster, "Pathogenic and opportunistic free-living amoebae: Acanthamoeba spp., Balamuthia mandrillaris, Naegleria fowleri, and Sappinia diploidea," FEMS Immunology and Medical Microbiology, vol. 50, no. 1, pp. 1-26, 2007.

[5] V. Thomas, J.-F. Loret, M. Jousset, and G. Greub, "Biodiversity of amoebae and amoebae-resisting bacteria in a drinking water treatment plant," Environmental Microbiology, vol. 10, no. 10, pp. 2728-2745, 2008.

[6] J. H. Diaz, "Increasing intracerebral infections caused by freeliving amebae in the United States and worldwide," Journal of Neuroparasitology, vol. 1, no. 1, pp. 1-10, 2010.

[7] N. Tsvetkova, M. Schild, S. Panaiotov et al., "The identification of free-living environmental isolates of amoebae from Bulgaria," Parasitology Research, vol. 92, no. 5, pp. 405-413, 2004.

[8] G. S. Visvesvara and J. K. Stehr-Green, "Epidemiology of freeliving ameba infections," Journal of Protozoology, vol. 37, no. 4, pp. 25S-33S, 1990.

[9] B. B. Gelman, S. J. Rauf, R. Nader et al., "Amoebic encephalitis due to sappinia diploidea," Journal of the American Medical Association, vol. 285, no. 19, pp. 2450-2451, 2001.

[10] Y. Qvarnstrom, A. J. Da Silva, F. L. Schuster, B. B. Gelman, and G. S. Visvesvara, "Molecular confirmation of sappinia pedata as a causative agent of amoebic encephalitis," Journal of Infectious Diseases, vol. 199, no. 8, pp. 1139-1142, 2009.

[11] V. Thomas, G. McDonnell, S. P. Denyer, and J.-Y. Maillard, "Free-living amoebae and their intracellular pathogenic microorganisms: Risks for water quality," FEMS Microbiology Reviews, vol. 34, no. 3, pp. 231-259, 2010.

[12] F. B. Sarica, K. Tufan, M. Çekinmez, B. Erdoğan, and M. N. Altinörs, "A rare but fatal case of granulomatous amebic encephalitis with brain abscess: the first case reported from Turkey," Turkish Neurosurgery, vol. 19, no. 3, pp. 256-259, 2009.

[13] H. Ertabaklar, M. Türk, V. Dayanir, S. Ertuğ, and J. Walochnik, "Acanthamoeba keratitis due to Acanthamoeba genotype T4 in a non-contact-lens wearer in Turkey," Parasitology Research, vol. 100, no. 2, pp. 241-246, 2007.

[14] S. Ozkoc, S. Tuncay, S. B. Delibas et al., "Identification of Acanthamoeba genotype T4 and Paravahlkampfia sp. from two clinical samples," Journal of Medical Microbiology, vol. 57, no. 3, pp. 392-396, 2008.
[15] H. Mergeryan, "The prevalence of Acanthamoeba in the human environment," Reviews of Infectious Diseases, vol. 13, no. 5, pp. S390-S391, 1991.

[16] G. Saygi, Z. Akin, and H. Tecer, "Isolation of Acanthamoeba and Naegleria spp. from soil and thermal water samples in Sivas," Acta Parasitologica Turcica, vol. 24, no. 3, pp. 237-242, 2000.

[17] A. Kilic, M. Tanyuksel, J. Sissons, S. Jayasekera, and N. A. Khan, "Isolation of Acanthamoeba isolates belonging to T2, T3, T4 and T7 genotypes from environmental samples in Ankara, Turkey," Acta Parasitologica, vol. 49, no. 3, pp. 246-252, 2004.

[18] Z. Zeybek, M. Ustunturk, and A. R. Binay, "Morphological characteristics and growth abilities of free living amoeba isolated from domestic tap water samples in İstanbul," IUFS Journal of Biology, vol. 69, no. 1, pp. 17-23, 2010.

[19] A. V. Smirnov and A. V. Goodkov, "An illustrated list of basic morphotypes of Gymnamoebia (Rhizopoda, Lobosea)," Protistology, vol. 1, no. 1, pp. 20-29, 1999.

[20] G. S. Visvesvara, "Pathogenic and opportunistic amebae," in Manual of Clinical Microbiology, P. R. Murray, E. J. Baron, J. H. Jorgensen, M. L. Landry, and M. A. Pfaller, Eds., pp. 2082-2091, ASM Press, Washington, DC, USA, 2007.

[21] M. A. T. Winck, K. Caumo, and M. B. Rott, "Prevalence of Acanthamoeba from tap water in Rio Grande do Sul, Brazil," Current Microbiology, vol. 63, no. 5, pp. 464-469, 2011.

[22] J. M. Schroeder, G. C. Booton, J. Hay et al., "Use of subgenic $18 \mathrm{~S}$ ribosomal DNA PCR and sequencing for genus and genotype identification of Acanthamoebae from humans with keratitis and from sewage sludge," Journal of Clinical Microbiology, vol. 39, no. 5, pp. 1903-1911, 2001.

[23] M. Schild, C. Gianinazzi, B. Gottstein, and N. Müller, "PCRbased diagnosis of Naegleria sp. infection in formalin-fixed and paraffin-embedded brain sections," Journal of Clinical Microbiology, vol. 45, no. 2, pp. 564-567, 2007.

[24] G. C. Booton, J. R. Carmichael, G. S. Visvesvara, T. J. Byers, and P. A. Fuerst, "Identification of Balamuthia mandrillaris by PCR assay using the mitochondrial 16S rRNA gene as a target," Journal of Clinical Microbiology, vol. 41, no. 1, pp. 453-455, 2003.

[25] D. Corsaro and D. Venditti, "Phylogenetic evidence for a new genotype of Acanthamoeba (Amoebozoa, Acanthamoebida)," Parasitology Research, vol. 107, no. 1, pp. 233-238, 2010.

[26] W. Nuprasert, C. Putaporntip, L. Pariyakanok, and S. Jongwutiwes, "Identification of a novel T17 genotype of Acanthamoeba from environmental isolates and T10 genotype causing keratitis in Thailand," Journal of Clinical Microbiology, vol. 48, no. 12, pp. 4636-4640, 2010.

[27] K. Tamura, D. Peterson, N. Peterson, G. Stecher, M. Nei, and S. Kumar, "MEGA5: molecular evolutionary genetics analysis using maximum likelihood, evolutionary distance, and maximum parsimony methods," Molecular Biology and Evolution, vol. 28, no. 10, pp. 2731-2739, 2011.

[28] J.-F. Loret and G. Greub, "Free-living amoebae: biological bypasses in water treatment," International Journal of Hygiene and Environmental Health, vol. 213, no. 3, pp. 167-175, 2010.

[29] C. Gianinazzi, M. Schild, B. Zumkehr et al., "Screening of Swiss hot spring resorts for potentially pathogenic free-living amoebae," Experimental Parasitology, vol. 126, no. 1, pp. 45-53, 2010.

[30] P.-M. Kao, B.-M. Hsu, N.-H. Chen et al., "Molecular detection and comparison of Acanthamoeba genotypes in different functions of watersheds in Taiwan," Environmental Monitoring and Assessment, vol. 184, no. 7, pp. 4335-4344, 2012. 
[31] J. Lorenzo-Morales, J. F. Lindo, E. Martinez et al., "Pathogenic Acanthamoeba strains from water sources in Jamaica, West Indies," Annals of Tropical Medicine and Parasitology, vol. 99, no. 8, pp. 751-758, 2005.

[32] D. Aitken, J. Hay, F. B. Kinnear, C. M. Kirkness, W. R. Lee, and D. V. Seal, "Amebic keratitis in a wearer of disposable contact lenses due to a mixed Vahlkampfia and Hartmannella infection," Ophthalmology, vol. 103, no. 3, pp. 485-494, 1996.

[33] M. W. Kuiper, R. M. Valster, B. A. Wullings, H. Boonstra, H. Smidt, and D. Van Der Kooij, "Quantitative detection of the free-living amoeba Hartmannella vermiformis in surface water by using real-time PCR," Applied and Environmental Microbiology, vol. 72, no. 9, pp. 5750-5756, 2006.

[34] N. A. Khan and T. A. Paget, "Molecular tools for speciation and epidemiological studies of Acanthamoeba," Current Microbiology, vol. 44, no. 6, pp. 444-449, 2002.

[35] N. A. Khan, E. L. Jarroll, and T. A. Paget, "Molecular and physiological differentiation between pathogenic and nonpathogenic Acanthamoeba," Current Microbiology, vol. 45, no. 3, pp. 197202, 2002.

[36] S. Rodriguez-Zaragoza, "Ecology of free-living amoebae," Critical Reviews in Microbiology, vol. 20, no. 3, pp. 225-241, 1994.

[37] J. M. Thomas and N. J. Ashbolt, "Do free-living amoebae in treated drinking water systems present an emerging health risk?" Environmental Science and Technology, vol. 45, no. 3, pp. 860-869, 2011.

[38] D. Corsaro, V. Feroldi, G. Saucedo, F. Ribas, J.-F. Loret, and G. Greub, "Novel Chlamydiales strains isolated from a water treatment plant," Environmental Microbiology, vol. 11, no. 1, pp. 188-200, 2009.

[39] D. Corsaro, G. S. Pages, V. Catalan, J.-F. Loret, and G. Greub, "Biodiversity of amoebae and amoeba-associated bacteria in water treatment plants," International Journal of Hygiene and Environmental Health, vol. 213, no. 3, pp. 158-166, 2010.

[40] R. M. Valster, B. A. Wullings, G. Bakker, H. Smidt, and D. Van Der Kooij, "Free-living protozoa in two unchlorinated drinking water supplies, identified by phylogenic analysis of $18 \mathrm{~S}$ rRNA gene sequences," Applied and Environmental Microbiology, vol. 75, no. 14, pp. 4736-4746, 2009. 

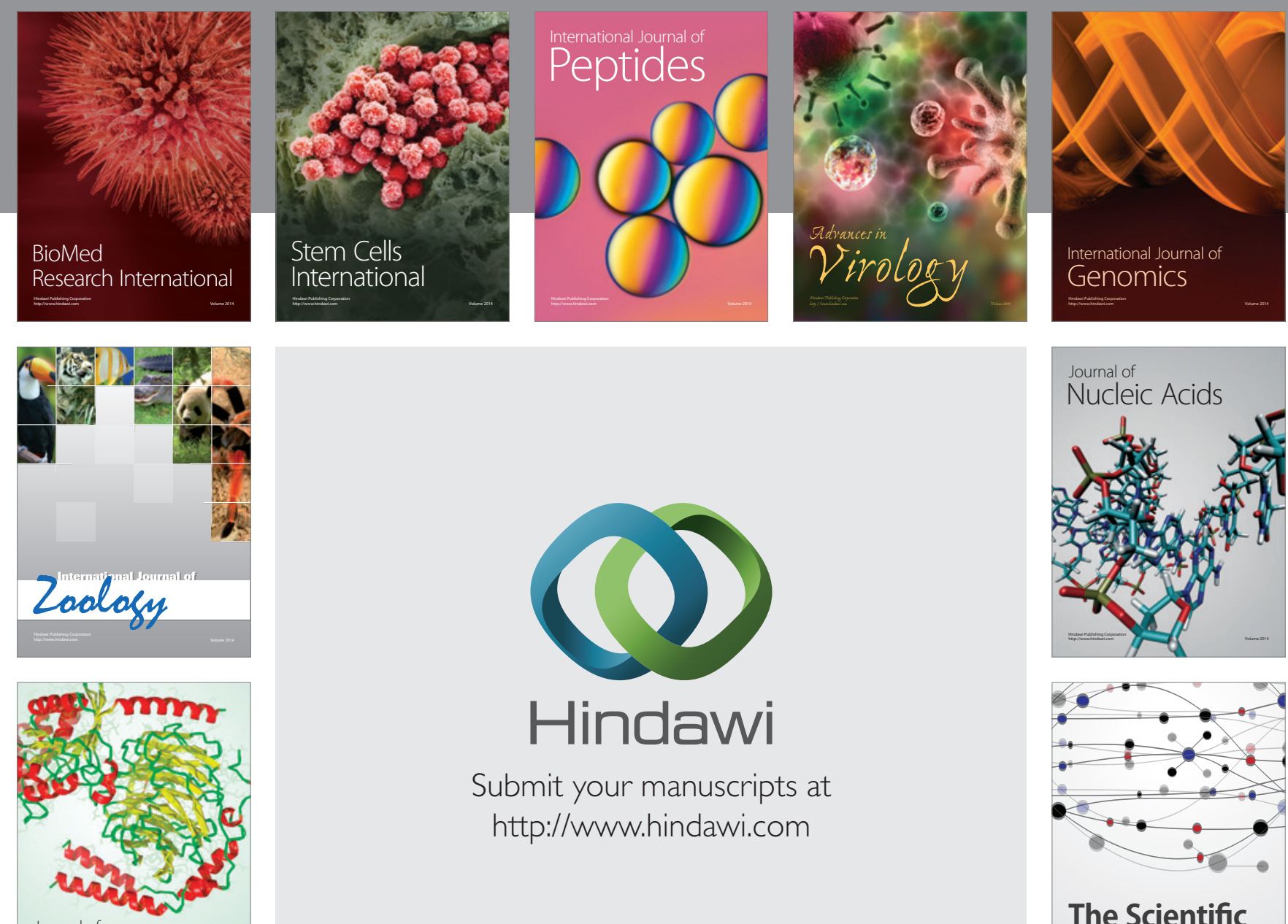

Submit your manuscripts at

http://www.hindawi.com

Journal of
Signal Transduction
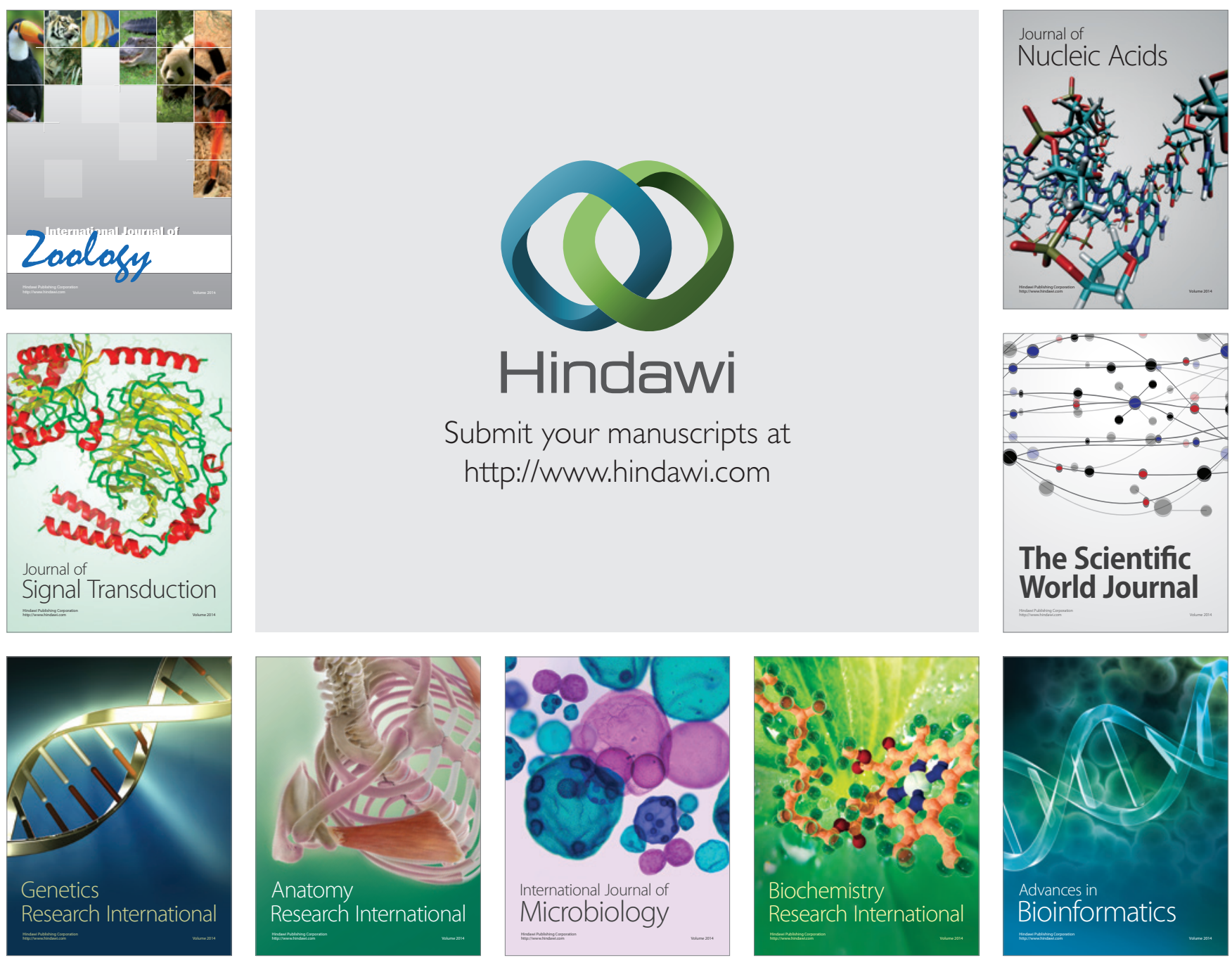

The Scientific World Journal
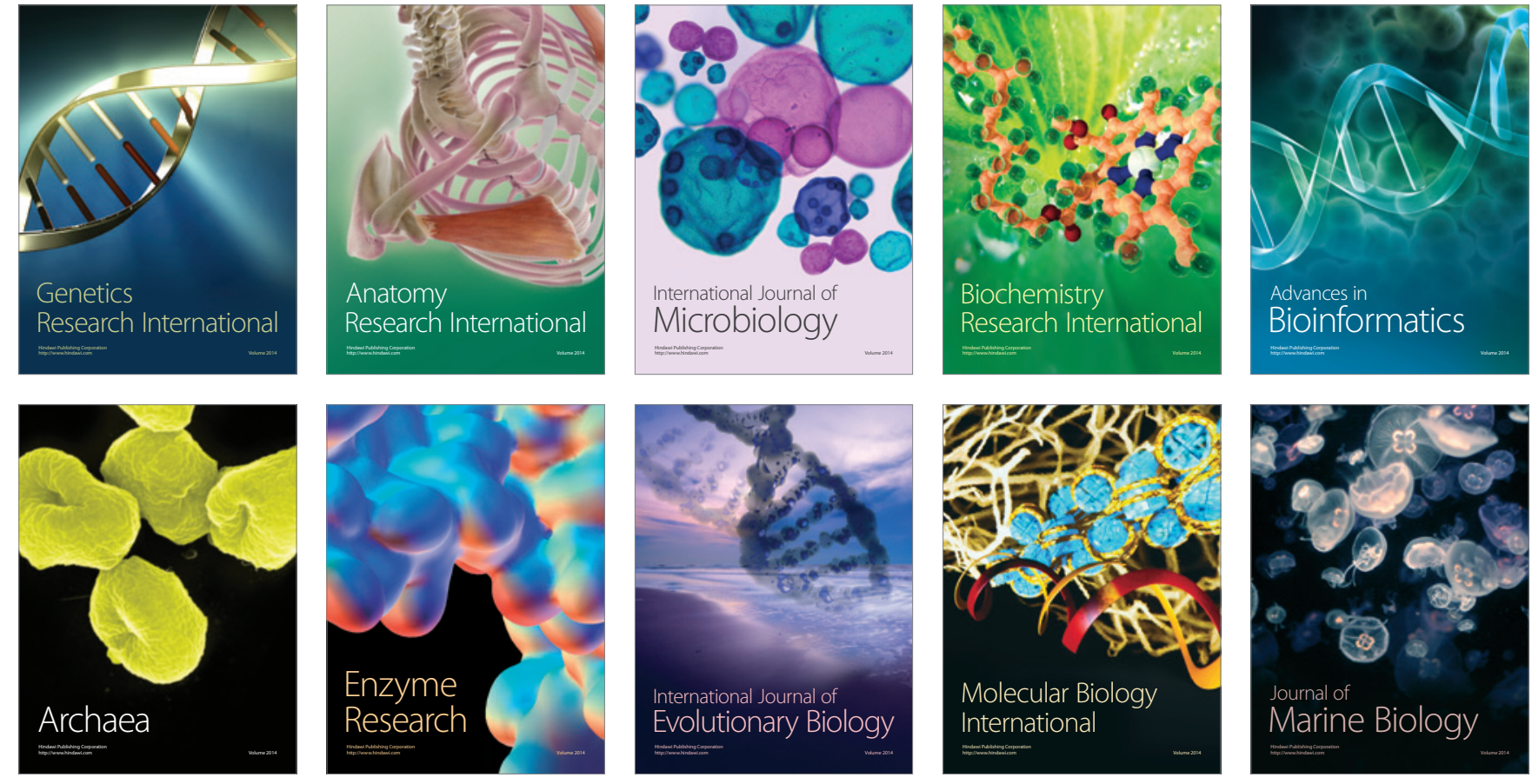